\title{
HOTEL RESERVATION POLICY PADA MASA PANDEMI : REFUND, RESCEDULE ATAU CANCEL DI LABUAN BAJO
}

\author{
Dyah Mustika Wardani \\ Universitas Bina Sarana Informatika, dyah.dyk@bsi.ac.id
}

\begin{abstract}
ABSTRAK
Dengan adanya pandemic, pembatalan pemesanan hotel meningkat, yang menyebabkan tergangunya operasional hotel dan menyebabkan banyak karyawan hotel yang akhirnya harus mengalami pemutusan hubungan kerja atau dirumahkan untuk sementara waktu. Penelitian ini dibuat untuk mengetaui apa saja yang menjadi pertimbangan tamu sehingga memutuskan untuk membatalkan pemesanan kamarnya, lalu bagaimana altenatif yang diberikan oleh hotel untuk mempertahankan agar tamu tetap memutuskan untuk datang di waktu yang lain. Metode penelitian yang digunakan dalam peneltian ini yaitu kualitatif. Sampel yang digunakan adalah hotel bintang 4 dan 3 dengan jenis hotel resort dan bisnis hotel yang ada di Labuan Bajo Nusa Tenggara Timur. Hasil penelitian menunjukkan bahwa altenative yang paling efektif digunakan yaitu melalui penjadwalan ulang pemesanan kamar dengan bentuk voucher yang dapat digunakan kapan saja tanpa batas waktu maksimal. Metode ini cukup efektif dalam membuat opeasional hotel tetap berjalan dan tidak merugikan tamu yang mengambil voucher tersebut.
\end{abstract}

Kata kunci : Hotel , Pemesanan kamar, Kebijakan

\section{ABSTRACT}

With the pandemic, cancellations of hotel bookings have increased, disrupting hotel operations and causing many hotel employees to end up being laid off or temporarily laid off. This research was made to find out what the guests considered so that they decided to cancel their room bookings, then how are the alternatives provided by the hotel to keep guests deciding to come at another time. The research method used in this research is qualitative. The samples used were 4 and 3 star hotels with the type of resort hotel and hotel business in Labuan Bajo, East Nusa Tenggara. The results showed that the most effective alternative to use was through rescheduling of room reservations in the form of vouchers that can be used anytime without a maximum time limit. This method is quite effective in keeping hotel operations running and not detrimental to guests who take the vouchers.

Keywords : Hotel, Reservation, Policy

\section{PENDAHULUAN}

Dimasa pandemic covid 19 menimbulkan banyak problematika untuk berbagai sektor. Dampak tersebut tentunya berimbas di sektor pariwisata dunia. Dari berbagai bidang pariwisata salah satunya yaitu industri perhotelan.

Indonesia yang tengah berpesta beberapa tahun terakhir, dengan adanya pandemic akhirnya mengalami keterpurukan yang sangat cepat. Pemulihan kondisi tersebut membutuhkan waktu yang cukup lama. Salah satu daerah yang tengah menjadi pusat perhatian wisatawan terutama Internasional adalah Labuan Bajo. Dengan demikian akhirnya mengubah daerah yang hanya sebagai tempat singgah bagi nelayan pada masa

ISSN: 2355-6587, e-ISSN: 2528-2220 
itu, saat ini menjadi destinasi wisata yang banyak dikunjungi oleh wisatawan internasional dan beberapa waktu yang lalu dijadikan sebagai salah destinasi prioritas oleh pemerintah Indonesia.

Situasi tersebut akhirnya mengundang para investor untuk turut menyumbang dan mempercepat pembangunan di Labuan Bajosalah satunya adalah akomodasi perhotelan. Karena kunjungan wisatawan Internasional cukup besar dibandingkan wisatawan domestik atau bisa dibilang segmentasi marketnya lebih banyak dari luar negeri.

Akhirnya dengan adanya pandemi sebagian besar hotel di Labuan Bajo banyak yang memutuskan untuk sementara menutup operaisonal hotelnya. Tidak banyak yang bisa dilakukan oleh hotel untuk mengantisipasi maupun keluar dari masalah tersebut Kondisi ini berdampak bagi sebagian karyawan hotel mengalami unpaid leave untuk sementara waktu.

Sebelum pandemic masuk ke Indonesia, disisi lain wisatawan nasional tengah ramai membicarakan kota kecil di ujung barat pulau Flores. Semakin banyak selebgram didatangkan untuk mempromosikan kota Labuan Bajo, hingga semakin banyak yang mulai populer dengan destinasi wisata di Labuan Bajo. Kunjungan wisatawan mulai meningkat seiring dengan perkembangan Objek wisata baru yang terus di buka dan diperbaiki infrastrukturnya. Dapat dilihat dari data dibawah ini bahwa pertumbuhan wisatawan terus mengalami kenaikan.

Tabel 1. Pengunjung Labuan Bajo

\begin{tabular}{|lrrrrr|}
\hline \multicolumn{5}{c}{ Bulan } & \multicolumn{5}{c}{ Pengunjung (Jiwa) } \\
& $\mathbf{2 0 1 8}$ & $\mathbf{2 0 1 7}$ & $\mathbf{2 0 1 6}$ & $\mathbf{2 0 1 5}$ & $\mathbf{2 0 1 4}$ \\
\hline Januari & 8626 & 14489 & 5458 & 7532 & 5998 \\
\hline Februari & 9199 & 4564 & 4759 & 4569 & 5842 \\
\hline Maret & 13668 & 10368 & 6733 & 5845 & 7818 \\
\hline April & 14217 & 8726 & 6075 & 7894 & 4887 \\
\hline Mei & 16681 & 9079 & 9698 & 8782 & 6875 \\
\hline Juni & 18901 & 10557 & 8370 & 7961 & 5009 \\
\hline Juli & 21186 & 13010 & 14757 & 9670 & 8857 \\
\hline Agustus & 24126 & 18554 & 14964 & 12727 & 11696 \\
\hline September & 17192 & 11987 & 10742 & 8809 & 6478 \\
\hline Oktober & 15883 & 8306 & 8935 & 8112 & 6119 \\
\hline November & 8832 & 7916 & 8328 & 7154 & 5582 \\
\hline Desember & 8324 & 7513 & 8892 & 6355 & 5465 \\
\hline
\end{tabular}

Sumber: BPS Manggarai Barat (2018)
Dengan data tersebut bisa dibuktikan bahwa pertumbuhan wisatawan baik dari domestik maupun mancanegara semakin naik.

Tentunya dengan hal tersebut berdampak pada industri perhotelan yang semakin berjaya. Sebagai salah satu contoh dampak yang terjadi selain harga bahan baku, kebutuhan sehari-hari semakin naik khusunya harga kamar hotel yang cenderung stabil dengan harga yang cukup mahal dibandingkan harga kamar hotel di wilayah bali dan jawa.

Kembali lagi dengan adanya pandemic tidak hanya wisatawan Internasional namun wisatawan nasional juga akhirnya mengurungkan niatnya untuk berkunjung ke Labuan bajo. Sebagian hotel ada yang masih tetap beroperasi meskipun dengan kondisi yang cukup minim. Bagi beberapa hotel yang segment marketnya adalah wisatawan Indonesia kondisi saat ini tidak terlalu berpengaruh namun hotel dengan segment marketnya adalah wisatawan dari mancanegara dipastikan menutup sementara hotelnya. Sebelum hotel tersebut mendapatkan segment market yang baru.

Dengan adanya penerbangan yang masih tersedia ke Labuan Bajo ada saja beberapa wisatawan yang tidak mengurungkan niatnya untuk berkunjung ke Labuan Bajo, meskipun berkurang drastis karena dipengaruhi oleh terbatasnya pergerakan wisawatan untuk melakukan perjalanan baik dari syarat yang harus di penuhi hingga secara finansial terdampak karena adanya covid 19 .

Saat ini sebagian besar tamu masih bersumber dari wisatawan domestik, berbagai alternative banyak di tawarkan oleh hotel. Berbagai metode tentunya tujuanya berujung pada satu harapan bahwa tamu akan tetap datang ke Labuan Bajo dan menginap pada hotel tersebut. Dimana masih tersisa harapan untuk kunjungan tamu dari wisatawan domestik yang masih memungkinkan bisa berkunjung ke Labuan Bajo.

ISSN: 2355-6587, e-ISSN: 2528-2220 
Dari hal tersebut tentunya menjadi penting bagi hotel untuk menganalisa apa yang menjadi tren dari wisatawan baik itu domestik maupun internasional. Upaya itu tentunya akan menjadi tolak ukur hotel untuk menentukan kebijakan apa saja yang cukup baik dalam memberikan kebijakan baik untuk hotel itu sendiri atau bagi tamu.

Dalam situasi saat ini salah satu section didalam hotel yang sedang berperan ekstra adalah bagian reservasi. Dimana kebijakan yang ada didalam reservasi akan berpengaruh terhadap occupansi sebuah hotel. Melalui penelitian ini bertujuan untuk mengetahui apa saja yang menjadi pertimbangan tamu sehingga banyak yang mengajukan pembatalan dan apa saja kebijakan yang dikeluarkan hotel sebagai altenatif yang diberikan agar tidak merugikan bagi hotel dan tamu. Dimana kebijakan tersebut akan berimbas pada kelangsuangan operasional hotel dan kepuasan tamu, karena tamu merupakan relasi terbaik dalam kemajuan sebuah industri perhotelan.

\section{KAJIAN LITERATUR}

Dalam bab kajian literatur ini terkait dengan Hotel reservation policy di masa pandemi . Pada Bagian pertama dalam kajian literatur membahas mengenai hotel yang menegaskan bagaimana hotel saat ini dikelola untuk terus menghasilkan revenue. Bagian kedua membahas mengenai kebijakan reservasi yang dibuat oleh sebuah hotel dalam mengatur pemesanan kamar dengan berbagai situasi dan kondisi yang mungkin terjadi.

\section{Hotel}

Menurut Sihite (2000) Hotel adalah suatu bentuk akomodasi yang dikelola secara komersial, disediakan bagi setiap orang untuk memperoleh pelayanan dan penginapan serta memperoleh makanan dan minuman.

Dewasa ini hotel telah berkembang tidak hanya sebatas tempat yang digunakan untuk menyediakan jasa penginapan, namun lebih komplek lagi ketika pertumbuhan dunia perhotelan menjadi lahan bisnis baru untuk menjadi venue dalam mengadakan berbagai macam event dan menyediakan fasilitas pendukung lainnya.

Sedangkan menurut Sulastiyono (2016) Hotel adalah tempat dimana para pelancong berkelas mendapat jasa penginapan dan makan dengan cara menyewa. Dan penyewa dalam keadaan memungkinkan untuk memperoleh jasa itu.

Seperti yang diketahui bersama bahwa kondisi yang terjadi saat ini bagi sebagai orang menginap di hotel adalah hal yang biasa terlebih ketika perkembangan hotel telah membidik berbagai jenis pelancong. Sehingga tidak hanya pelancong berkelas yang dapat menikmati jasa penginapan, namun semua kalangan masyarakat dapat memilih jenis jasa sesuai denga isi kantorngnya masing masing.

\section{Reservasi}

Menurut Monaghan(2006) Reservasi adalah sebuah proses klerikal atau klerikal atau elektronik dimana produk perjalanan seperti tiket pesawat, kamar hotel, kamar pada kapal pesiar tersedia untuk dipakai dan pada akhirnya dibeli oleh individu secara spesifik. Kata reservasi dalam dunia pariwisata disebut dengan booking.

Dalam konteks ini reservasi berfokus pada industri perhotelan. Untuk melakukan reservasi dapat dilakukan dengan berbagai macam cara baik secara offline maupun secara online.

Menurut Mayasari (2011:20), Reservasi secara umum dapat diartikan sebagai penyediaan tempat duduk, yang meliputi keseluruhan proses kegiatan yang berkatian dengan pendistribusian produk, pencatatan keseluruhan transaksi pemesanan tempat untuk pencapaian pendapatan yang optimal.

Dengan adanya reservasi akan mempermudah seseorang dalam kepastian dalam mendapatkan kamar terutama dimasa high session. Melakukan reservasi selain akan mempermudah bagi tamu yang datang tetapi juga akan memberikan kepastian terhadap berapa besar occupancy yang akan didapan oleh hotel. 


\section{METODE PENELITIAN}

Dalam penelitian ini menggunakan metode penelitian kualitatif. Penelitian kualitatif tidak fokus dengan angka dan nilai namun lebih dalam menjelaskan sebuah kejadian berdasarkan dengan narasi. Menurut Sugiyono(2005) metode penelitian kualitatif adalah penelitian yang digunakan untuk meneliti pada kondisi objek alamiah, dimana peneliti merupakan instrument kunci.

Pada dasarnya kualitas penelitian kualitatif dapat dilihat dari berapa luas pengetahuan yang dimiliki oleh penulisny dan kekuatan dalam menyusun kata kata merupakan kunci utama seperti yang dikemukakan oleh Moleong(2005:6) penelitian kualitatif adalah penelitian yang bermaksud untuk memahami fenomena tentang apa yang dialami oleh subjek penelitian misalnya perilaku, persepsi, motivasi, Tindakan, dll secara holistic dan dengan cara deskripsi dalam bentuk katakata dan bahasa, pada suatu konteks khusus yang alamiah dan dengan memanfaatkan berbagai metode alamiah.

\section{PEMBAHASAN}

Labuan Bajo yang sudah mulai populer saat ini tentunya menyisakan banyak cerita. Perkembangan dalam sisi manapun merupakan topik yang menarik untuk dibahas. Sebagai tempat dengan daya tarik wisata yang mempesona tentunya membuat banyak orang Menyusun rencana perjalanan ke pulau tersebut. Berbagai akomodasi mulai banyak dibangun, salah satunya yaitu hotel.

Hotel merupakan salah satu akomodasi yang menyiapkan berbagai fasilitas sebagai tempat tinggal sementara bagi para wisatawan yang berkunjung ke Labuan Bajo. Dengan berbagai konsep yang disuguhkan oleh setiap hotel tentunya menjadi warna tersendiri dalam menghiasi kota Labuan Bajo sebagai destinasi prioritas.

Setiap hotel mempunyai segment market yang berbeda, hal ini didasari oleh konsep hotel itu sendiri dan biasa di kenal dengan beberapa bentuk. Salah satunya yaitu konsep resort. Yang menjadi segment market resort adalah tamu leisure. Dimana hotel akan menawarkan berbagai alternative objek wisata melalui salah satu strategi pemasaran yaitu menawarkan paket menginap tiga hari dua malam (3D $2 \mathrm{~N}$ ) dengan opsi yang diberikan tentunya akan membuat tamu untuk tinggal lebih lama dan hal ini akan berdampak pada peningkatan revenue sebuah resort.

Selain resort di Labuan Bajo juga terdapat business hotel, untuk tipe ini tentunya segment marketnya menyasar pada corporate dan goverment. Sehinga hotel menyiapkan fasilitas pendukung untuk memenuhi kebutuhan mereka yaitu meeting room, ball room atau ruangan sejenisnya yang berfungsi sama yaitu untuk mengadakan sebuah event. Sepanjang beberapa tahun terakhir Labuan Bajo sedang berpesta.

Kunjungan wisata yang semakin meningkat drastis diiringi dengan begitu banyak investor yang mulai turut membangun Labuan Bajo yang mengakibatkan pesatnya perkembangan dunia perhotelan di kota labuan bajo.

Tabel 2. Perkembangan Akomodasi

\begin{tabular}{lrrrrrr}
\hline $\begin{array}{c}\text { Akomodasi } \\
\text { Hotel }\end{array}$ & $\mathbf{2 0 1 8}$ & $\mathbf{2 0 1 7}$ & $\mathbf{2 0 1 6}$ & $\mathbf{2 0 1 5}$ & $\mathbf{2 0 1 4}$ \\
\hline $\begin{array}{l}\text { Jumlah Hotel } \\
\text { Jumlah }\end{array}$ & 98 & 76 & 64 & 60 & 56 \\
$\begin{array}{l}\text { Kamar } \\
\text { Jumlah }\end{array}$ & 1462 & 1191 & 1030 & 994 & 914 \\
$\begin{array}{l}\text { Tempat Tidur } \\
\text { Sumber: BPS Manggarai Barat (2018) }\end{array}$ & 3029 & 2262 & 1697 & 1540 & 1435 \\
\hline
\end{tabular}

Data diatas menunjukkan bahwa selama 5 tahun terakhir perkembangan pembangunan hotel di Labuan Bajo setiap tahun mengalami peningkatan. Selain melalui data diatas potensi industri perhotelan dapat dilihat melalui harga kamar sebuah hotel yang tidak kunjung turun meskipun semakin banyak hotel yang dibangun.

Namun pada tahun 2020 seluruh dunia sedang mengalami keterpurukan oleh pandemic covid 19. Seperti dilangsir dari laporan IMF yang berjudul Global Financial Stability Overview, Oktober 
2020. Menunjukkan bahwa ekonomi dunia membutuhkan pemulihan.

Kondisi ini berdampak besar didalam dunia pariwisata salah satunya di dunia perhotelan. Seperti layaknya pesta yang mulai berakhir dan belum bisa dipastikan kapan pesta itu akan dimulai kembali. Sebagian hotel berhenti untuk beroperasi dan sebagian lainya tetap bertahan dengan segala kondisinya.

Berdasarkan hasil interview dengan beberapa narasumber dengan jenis hotel resort sebagian menutup sementara operasional hotelnya dengan waktu rata rata sekitar satu sampai dengan dua bulan dimasa pandemic sedang mulai mewabah. Sedangkan untuk bisnis hotel yang mana segment marketnya merupakan goverment dan corporate tidak ada yang menutup hotelnya selama masa pandemic.

Meskipun dengan segala konsekuensinya sebagai contoh sebagian karyawan yang masih casual atau daily worker terpaksa unpaid leave atau sebagai yang lain gaji karyawan dibayarkan sebesar $50 \%$.

Permasalahan yang terjadi selain dari internal hotel dengan adanya Force majeurtentunya menyisakan banyak pekerjaan yang masih menggantung dari tamu maupun dari sisi manajemen. Tamu hotel di Labuan Bajo tidak semua datang melalui walk in mengingat Labuan Bajo merupakan sebuah pulau, dari sini bisa di pahami bahwa kedatangan tamu sebagian besar melalui sebuah reservasi baik itu dari tamu GIT (Group Intesive Tourist) maupaun dari FIT (Free Individual Tourism).

Dimana yang kita tau bahwa pandemic menyebar dengan sangat cepat, sudah dipastikan banyak orang yang sudah merencakan kedatanganya untuk mengina namun menjadi sebuah masalah baru ketika suluruh penerbangan dihentikan, wilayah mulai di lock down dan negara dilarang menerima wisatawan. Dampk tersebut tentunya membuat tamu yang sudah merencanakan berlibur harus memilih antara cancel atau harus menunda.
Dengan berbagai permasalah yang terjadi dan kebijakan yang ada disebuah hotel point penting saat ini adalah bagaimana hotel tetap mendapatkan revenue dan dapat beroperasional kembali.

Dari berbagai kebijkan yang telah diperbarui reservation policy merupakan salah satu faktor penentu revenue dalam sebuah hotel saat ini. Mengapa hal ini dapat terjadi karena dengan adanya terobosan kebijakan yang baru diharapkan kebijakan tersebut dapat mempertahankan tamu untuk tetap tinggal dan menginap di sebuah hotel di Labuan Bajo.

Ketika membahas mengenai sebuah reservation policy di dalam hotel yang menjadi komponen penting untuk dibahas dalam konteks reservation policy yaitu bagaimana mengemas kebijakan tersebut agar tetap sesuai tujuan yaitu tamu tetap memilih menginap di sebuah hotel.

Komponen penting dalam kebijakan reservasi didalam hotel saat ini antara lain :

\section{Refund}

Refund merupakan salah satu altenatif yang di pilih oleh sebagian orang yang telah memesan hotel di Labuabajo. Pemesanan hotel saat ini dibagi menjadi dua point penting yaitu pemesanan langsung di hotel atau melalui online travel agent. Pemesanan hotel melalui travel mengacu pada tiga komponen penting terkait pembatalan hotel non-refundable. Partially refundable, atau fully refundable.

Yang dimaksud dengan nonrefundable artinya ketika seseorang memesan kamar yang tidak ada ketentuan untuk di refund namun karena situasi pandemic akhirnya mengajukan untuk refund berarti customer sama dengan memesan kamar hotel dengan harga baru ( full harga yang berlaku sesuai dengan tanggal di booking), sedangkan partially refundable artinya bahwa pembatalan pemesanan kamar hotel akan dikenakan biaya tergantung dari syarat dan ketentuan hotel yang telah dipesan dan untuk fully refundable berarti ketika customer menginginkan untuk cancel booking tidak akan dikenakan biaya.

ISSN: 2355-6587, e-ISSN: 2528-2220 
Pada masa ini pilihan refund meningkat drastis hingga mencapai angka 10 kali lipat dari sebelum masa pandemi. dilangsir dari pernyataan salah satu Chief Marketing Officer Traveloka pada Kompas.com.

Meski saat ini banyak keluhan yang terjadi antara lain adalah para customer yang memesan melalui travel agent mengalami keterlambatan masa pengembalian dana yang telah dibayarkan. Dalam situasi ini dipengaruhi oleh sulitnya alur proses refund karena terkendala oleh system yang digunakan travel agent. Seperti yang disampaikan oleh Sekretaris Jenderal Asosiasi Travel Agent Indonesia (Astindo)

Di Kompas.com, Kenyataanya bahwa memesan kamar melalui online travel agent tergolong lebih murah, namun sebagian orang mengabaikan syarat dan ketentuan yang diberlakukan oleh pihak travel agent, yang akhirnya baru disadari pada situasi seperti saat ini bahwa hotel yang telah dipesan diketahui tidak dapat di refund.

Sedangkan reservasi yang dilakukan langsung ke hotel lebih menguntungkan ketika dikaitkan dengan harga. Harga pemesanan kamar langsung ke hotel memang tidak banyak discount atau tergolong stabil sesuai dengan room rate yang berlaku didalam hotel tersebut. Namun kemudahan yang diberikan terkait dengan kebijakan dan hal lainya dalam situasi tertentu akan lebih mudah untuk dinegosiasikan. Refund yang diberikan oleh hotel terhadap tamu dapat dilihat dari prioritas tamu tersebut. Namun dalam situasi force majeur kebijakan untuk full refundable diberlakukan dengan syarat dan ketentuan yang berlaku.

Proses dalam mengajukan refund setiap hotel berbeda-beda, namun pada prinsipnya sama yaitu setiap kebijakan reservasi yang diberikan tentu berlaku untuk semua tamu baik domestic maupun dari tamu mancanegara.

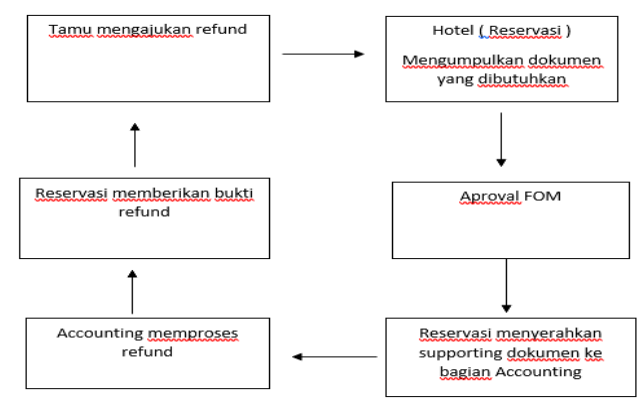

Gambar 1. Proses Refund

Sumber: Inayabay (2019)

Dewasa ini untuk tamu yang reservasi langsung melalui hotel ketika mengajukan refund biasanya akan di arahkan untuk reschedule dengan menggunakan sebuah voucher. Salah satu terobosan sebagai alternatif agar industri tidak banyak megalami kerugian dan saat ini sedang poluler digunakan oleh hotel adalah menggunakan sebuah voucher atau dikenal dengan open voucher. Yang dimaksud dengan open voucher adalah salah satu voucher yang dapat digunakan oleh tamu untuk menginap dalam sebuah hotel dalam bentuk open date dimana tamu dapat melakukan reschedule kapan saja tanpa ada batas expire date.

Ditemukan fakta menarik bahwa sebagian besar wisatawan dari mancanegara yang melakukan refund, sedangkan untuk wisatawan dalam negeri memilih untuk menunda waktu. Sebagian besar sudah menunggunakan voucher tersebut pada tahun 2020 yang lalu. Kemudian bagi tamu prioritas atau biasa disebut dengan repeat guest ketentuan refund diberikan fully refund karena merupakan tamu prioritas dari sebagian hotel di Labuan Bajo.

\section{Reschedule}

Metode ini adalah salah satu yang saling menguntungkan dari kedua sisi baik dari tamu maupun dari manajemen. Faktanya tamu hotel di Labuan Bajo yang melakukan reschedule pada awal pandemic sudah terselesaikan di tahun 2020. Namun dengan satu catatan bahwa tamu tersebut merupakan tamu yang berasal dari Indonesia atau tamu dari mancanegara

ISSN: 2355-6587, e-ISSN: 2528-2220 
yang selama pandemic masih berada di Indonesia.

Kebijakan yang baru akhirnya mulai diubah, dimana dulu kebijakan dalam reschedule hanya dapat dilakukan sekali, saat ini dibuat kebijakan baru dengan memberlakukan kebijakan reschedule yang dapat dilakukan berkali kali atau biasa disebut dengan open date, mengingat kondisi saat ini yang masih belum bisa dipastikan kapan akan pulih kembali.

Dengan segala kemudahan yang diberikan tententunya tidak luput dari term and condition yang telah dibuat oleh hotel. Pada umumnya kebijakan untuk rechedule dapat dilihat dari jenis hotelnya. Pada resort kebijakan reschedule umumnya di lakukan tujuh hari sebelum waktu check in ,sedangkan untuk hotel bisnis memberlakukan tiga hari sebelum waktu check in. Keduanya berlaku untuk jenis tamu FIT ( Free Independent Traveler ) baik dari corporate maupaun dari government. Sedangkan untuk tamu group atau mice dapat melakukan reschedule empat belas hari sebelum kedatangan.

Sampel yang diambil dari industri terkait dengan pemetaan kebijakan yang diambil mengenai kebijakan reservasi dari setiap hotel menunjukan data berikut ini:

Tabel 3. Kebijakan Reservasi

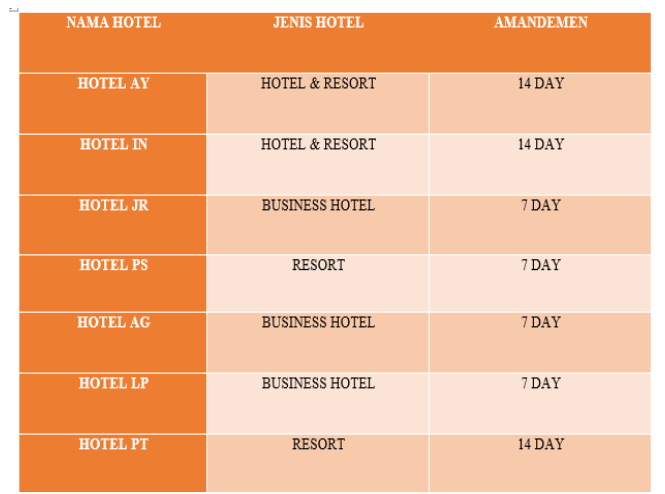

Sumber : Wardani (2021)

Dari data tersebut disimpulkan bahwa sebagian hotel di Labuan Bajo saat ini memberlakukan minimal one weeks prior to arrival yang dimaksud adalah pemberitahuan kepada bagian reservasi minimal satu minggu sebelum voucher itu digunakan. Namun bagi hotel yang sedang hectic biasanya akan memberlakukan one month prior to arrival atau two weeks prior to arrival bagi resort. Ketentuan ini dibuat untuk mengantisipasi bagaimana jika bertepatan dengan libur panjang atau kedatangan tamu group.

Meskipun tamu yang berkunjung ke beberapa hotel di Labuan Bajo merupakan wisatawan yang berasal dari mancanegara dan domestik namun kebijakan reschedule yang ada didalam hotel antara tamu yang berasal dari mancanegara dengan tamu yang berasal dari domestik tidak ada bedanya.

Kebijakan dan SOP yang digunakan dalam menangani kasus reschedule sebagian besar hotel hampir sama. Oleh beberapa hotel tamu FIT ketika mengajukan permintaan rechedule kepada pihak hotel dapat melalui telepon, email atau whatsapp yang akan di konfirmasi oleh pihak hotel berdasarkan ketentuan waktu yang berlaku dihotel tersebut.

Pihak reservasi akan mengajukan persetujuan kepada head of department, setelah memenuhi syarat untuk melakukan reschedule permintaan akan di setujui dan bagian reservasi akan mengirim official letter melalui email kepada tamu yang mengajukan reschedule. reschedule :

Berikut ini merupakan proses

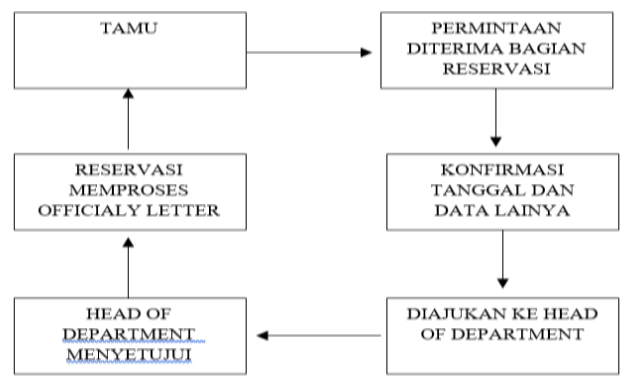

Gambar 2. Proses Rescedule Sumber: Accor (2014)

Prosedure untuk reschedule tidak mengalami perubahan, hanya saja saat ini kebijakan yang diberikan oleh hotel lebih mudah. Setiap prosedur yang berlaku digunakan untuk seluruh tamu baik untuk tamu domestik maupun tamu dari mancanegara. 


\section{Cancel}

Dalam kondisi saat ini pilihan untuk cancel menjadi tren tamu mancanegara. Ditemukan fakta sebagian hotel yang berada di Labuan Bajo, banyak mendapati tamu yang melakukan cancel. Tamu ini di dominasi oleh tamu FIT dan GIT dari mancanegara. Hal ini berkaitan dengan dihentikannya kunjungan wisata dari mancanegara oleh berbagai maskapai. Ketidakpastian kapan akan berakhir pandemi saat ini menjadi bahan pertimbangan yang paling utama bagi sebagian besar wisatawan mancanegara.

Segala upaya telah diusahakan oleh hotel untuk dapat mempertahankan kujungan tamu, namun karena situasi Force majeur membuat tamu harus memutuskan untuk reschedule atau cancel.

Yang dimaksud dengan cancel dalam kebijakan ini adalah tamu yang sudah melakukan pemesanan atau reservasi di dalam sebuah hotel dan sudah melakukan deposit kepada pihak hotel. Kebijakan lama yang berlaku ketika tamu mengajukan pembatalan pemesanan kamar, pihak hotel akan mengambil kebijakan dengan memberikan charge atau membayar denda.

Kebijakan yang dimaksud dengan memberikan denda ini pun beragam, yang paling umum adalah bagi tamu yang menginap lebih dari satu malam akan dikenakan charge satu malam, sedangkan tamu yang menginap hanya satu malam deposit yang telah diberikan kepada hotel akan hangus. Pada dasarnya kondisi ini disesuaikan dengan kapan cancel itu dilakukan.

Jika pemesanan dilakukan melalui Travel agent ketika tamu hanya menginap satu malam dan berkeinginan untuk cancel atau refund pemesanan, dikembalikan lagi melalui apa tamu memesan kamar tersebut. Karena sebagian besar OTA memang tidak memberlakukan adanya refund, namun ketika ada kebijakan refund dikembalikan lagi berdasarkan mekanisme dari OTA.
Kebijakan pembatalan didalam hotel dapat dilihat prosesnya pada gambar dibawah ini.

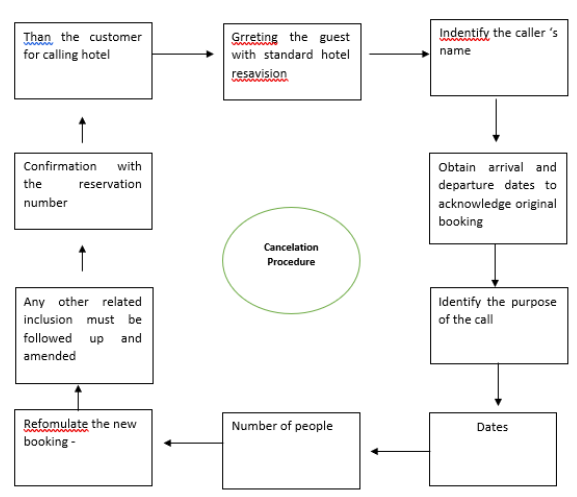

Gambar 3. Proses Pembatalan Sumber : Accor (2014)

Dari gambar diatas menunjukkan proses yang harus dilalui oleh tamu ketika mengajukan pembatalan pemesanan kamar. Dalam proses pembatalan pemesanan kamar didalam hotel berlaku untuk untuk semua jenis tamu baik tamu domestik maupun mancanegara.

Sehubung dengan adanya situasi saat ini seluruh hotel pun akhirnya mengeluarkan kebijakan yang mana ketika terjadi Force majeur hotel akan memberikan alternative lain.

Pada masa pandemic kerugian tidak hanya dirasakan oleh tamu namun pihak industri pun tentunya juga terdampak. Sebagian hotel di Labuan Bajo memberlakukan beberapa pilihan dimana opsi untuk cancel dengan mengembalikan deposit $100 \%$ namun belum menjadi pilihan terbaik yang ditawarkan kepada tamu. atau reschedule

Ada beberapa alternative yang di tawarkan kepada tamu yaitu dengan memberikan kemudahan untuk melakukan reschedule dengan bentuk voucher yang dapat digunakan kapanpun oleh tamu dengan beberapa ketentuan yang telah dibahas pada pembahasan reschedule.

Selanjutnya pilihan yang diberikan oleh manajemen hotel yaitu kepada tamu tamu yang tergolong loyal guest atau repeater guest dan sudah melakukan reservasi, pihak hotel akan mengembalikan

ISSN: 2355-6587, e-ISSN: 2528-2220 
uangnya $100 \%$, pilihan ini dilakukan dalam rangka menjaga bussines comitment atau kerjasama meskipun dalam konteks ini hotel memilih untuk merugi.

Dengan adanya Force majeur dan akhirnya menimbulkan banyak tamu yang melakukan cancel menimbulkan banyak sekali kerugian bagi tamu maupun bagi pihak hotel, situasi tersebut tentunya akan memberikan dampak pada seluruh pegawai hotel dan terhambatnya operasional hotel yang akhirnya sebagian hotel memutuskan untuk menutup hotelnya sementara waktu.

\section{PENUTUP}

Pembahasan mengenai reservation policy dari beberapa hotel di Labuan Bajo dapat digaris bawahi pada beberapa point penting. Kebijakan dalam pemesanan kamar dapat dikategorikan menjadi tiga point penting yaitu refund, reschedule dan cancel. Perubahan yang terjadi saat ini dengan kondisi Force majeur yang artinya seluruh hotel harus memberlakukan kebijakan khusus dalam masa pandemi.

Kebijakan baru yang diberlakukan meskipun ada sisi saling merugikan, merugikan salah satunya atau sama sama menguntungkan. Yang harus dihadapi ketika sebagian besar tamu di Labuan Bajo memutuskan untuk membatalkan perjalanannya, dimana manajemen dituntut untuk dapat mempertahankan tamu agar tetap menginap dihotel tersebut. Upaya terus dilakukan supaya revenue terus masuk dimasa seperti ini.

Dapat disimpulkan bahwa saat ini terdapat beberapa kebijakan baru yang disesuaikan dengan adanya pandemi.

Kebijakan baru yang muncul ketika tamu menginginkan untuk refund dan cancel saat ini hotel memberikan kebijakan dengan memberikan voucher menginap dalam bentuk open date yang artinya tidak ada batas waktu sehingga kapanpun voucher tesebut dapat digunakan dengan term and condition tertentu salah satunya seminggu sebelum voucher digunakan atau sebulan sebelum voucher digunakan untuk melakukan reservasi terlebih dahulu.
Sebelum adanya Force majeur setiap tamu yang melakukan cancel akan dikenakan charge satu malam atau masa pemesanan hotel akan hangus jika hanya menginap satu malam. Dalam hal ini dapat dilihat melalui apa reservasi itu dilakukan dan kapan waktu untuk melakukan pembatalan pemesanan kamar. Karena bagi pemesanan yang melalui OTA waktu itu akan berpengaruh terhadap presentase refund.

Ketentuan reschedule tentunya akan disesuikan dengan kondisi dimana tamu menginginkan kapan waktu akan menginap apakah pada saat high season atau low season.

Namun ada pengecualian bagi sebagian hotel ketika repeater guest menginginkan untuk cancel, deposit yang sudah masuk didalam hotel akan di refund 100\% kepada loyal guest.

Pada kesimpulanya metode pemsanan kamar pada hotel sebagian besar diarahkan untuk reschedule dengan ketentuan dapat dilakukan berkali kali atau dapat menggunakan voucher tanpa expire date. Langkah ini merupakan salah satu solusi terbaik bagi tamu dan manajemen. Sehingga tidak ada yang dirugikan diantara keduanya.

Dalam menidaklanjuti dari hasil penelitian ini tentunya dibutuhkan penelitian lanjutan mengenai bagaimana akhirnya hotel di Labuan Bajo bertahan dengan adanya pandemic, hal ini tentunya berkaitan dengan adanya segment market dan bagaimana strategi pemasaran yang di upayakan oleh Sebagian hotel untuk tetap mendapatkan revenue sehingga operasional hotel kembali normal.

\section{REFERENSI}

Sihite. (2000). Hotel Management( Pengelolaan Hotel). Surabaya:SIC

Sulastiyono.(2006). Teknik dan Prosedur Divisi Kamar pada Bidang Hotel.

Pradiatiningtyas. 2017. Pengaruh Web Experience, Sosial factor, dan ease of use terhadap penggunaan 
reservasi hotel secara online. Vol 8 Nomor.2 .70-76

Prabowo \& Retnonigsing.2017.Sistem Informasi Reservasi Kamar pada hotel Posters MICE. Vol 1 Nomor 2.147-160

Limbardo,. 2007, Analisis dan perencanaan system reservasi hotel Berbasis internet ( studi kasus pada hotel classic pt, Buana mitra usaha.Indergraduate thesis. Universitas Binus.

Monaghan. 2009,. The Travel Agen's Complete Desk reference $5^{\text {th }}$ Edition. Jakara: Intrepid Traveler.

Djamali, Radjab. 2019. Reservation and Ticketing.

Wijaya.2020. Batalkan pesanan hotel dapat refund. Bagaimana caranya.https://travel.kompas.com/r ead/2020/01/31/123300727/batalkan -pesanan-hotel-dan-dapat-refundbagaimana-caranya-

Asian Destinasi. 2020. Aturan pembatalan reservasi hotel terkait wabah virus corona.https://destinasian.co.id/atura n-pembatalan-reservasi-hotel terkaitwabah-virus-corona/

Marina. 2021. Syarat dan ketentuan reservasi hotel. https://id.marinabaysands.com/hotel/ terms-and-conditions.html

The sultan jogja heritage. 2021. Kebijakan hotel.https://www.sultanjakarta.com/ id/page/policy

Booking. Com. 2021. Syarat dan ketentuan perjalanan.https://www.booking.co $\mathrm{m} /$ content/terms.id.html

IMF .2020. Global Financial Stability Report: Bridge to Recovery https://www.imf.org/en/publications /gfsr.

\section{BIODATA PENULIS}

Dyah Mustika Wardani, dilahirkan di Kota Gunungkidul, 05 Januari 1992. Merupakan lulusan tahun 2013 dari. Diploma III Perhotelan di STIPRAM,. Pada tahun berikutnya melanjutkan ke jenjang Sarjana Pariwisata (Hospitality) di STIPRAM dan telah diselesaikan pada tahun 2015. Telah bekerja pada berbagai bidang baik instansi pemerintah, dinas pariwisata, hotel, restaurant serta mendirikan Travel Agent dan pada tahun 2017 atas ijin tuhan dapat melanjutkan studi program Magister Manajemen STIPARY. Pada tahun 2018 mendapat kesempatan bergabung pada salah satu perguruan tinggi swasta yang berada di NTT sebagai tenaga pengajar dalam bidang budaya, hotel dan manajemen, selain itu mendapat jabatan structural sebagai sekertaris Direktur. Pada tahun 2019 berhasil menyelesaikan Program Magister dan diangkat menjadi Wakil Direktur II bidang Non akademik. Selain itu tergabung sebagai sebagai tim penyusun desain perencanaan kuliner dan wisata dari Kementerian Pariwisata. Pada tahun 2020 penulis mendapat kesempatan untuk mengajar di UBSI Bekasi di Program Studi D3 Perhotelan dan saat ini selain mengajar juga sebagai Owner salah satu restaurant dan café di Kota Bekasi.

ISSN: 2355-6587, e-ISSN: 2528-2220 